\title{
In Memoriam: Professor Alain Vautrin
}

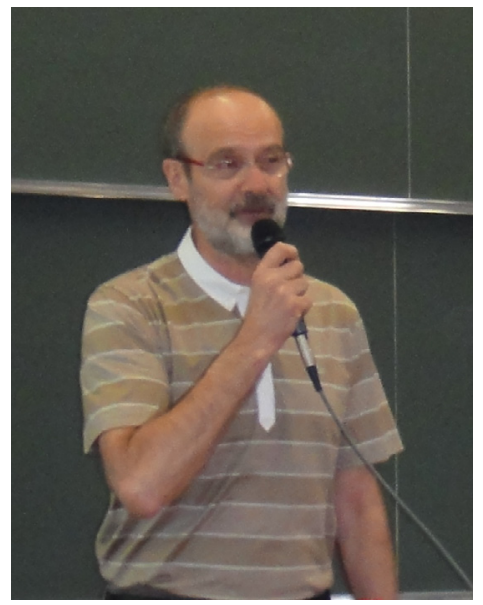

Alain Vautrin died suddenly at the age of 62 , while cycling during the Whitsun weekend.

This sad news has struck a terrible blow to the community of mechanical engineers.

Alain Vautrin was a Professor at the École des Mines de Saint-Étienne, very active in his near environment and always ready to contribute towards bringing the mechanical sciences to the fore at national and international levels.

An engineer graduated from the École Nationale Supérieure d'Électricité et de Mécanique (ENSEM) in 1972, he was awarded a PhD in Engineering Science by the Institut National Polytechnique de Lorraine (INPL) in 1976 and obtained a Doctorat ès sciences physiques in 1983.

During his stay in Nancy, he set up a genuine hub of expertise relating to the thermo-rheology of composite materials. The Laboratoire d'Énergétique et de Mécanique Théorique et Appliquée (LEMTA) to which he was assigned is greatly indebted to him.

He left the LEMTA and the ENSEM in the fall of 1983, when he was seconded to the École des Mines de Saint-Étienne, where he continued his brilliant career.

As Professor at the INPL in 1987, he continued his research activity at the École des Mines de Saint-Étienne, while seconded, and was appointed Director of Research in 1989 and Professor in 1992 of the same school, where he worked up to his death.

His scientific output was considerable throughout his career; his research themes concerned applications ranging from photomechanics to the identification of composite materials, processes for producing composites by infusion and by the injection of molten polymers, and the durability of stratified composite materials.

He taught structural mechanics and materials in the third year of the school and in the framework of the MS in Structural Engineering and Materials. But above all he was the Director of PhD School 488, "Sciences, Engineering and Health", from September 2007 onwards and greatly contributed to this school's reputation.

Throughout his career, he trained many researchers who remained strongly attached to him and recognised his considerable scientific and human qualities.

However, what is most striking is certainly his resolute effort to develop the field of mechanical engineering in both national and international institutions.

In particular, he was a representative of the Scientific and Technical Mission of the Ministry of Higher Education and Research, a pedagogical expert for the Department of Higher Education, and a scientific delegate with the Research and Higher Education Evaluation Agency.

He gave a great amount of time to the Association Universitaire de Mécanique (AUM) and to the Association Française de Mécanique (AFM), where he coordinated the scientific and technical group dedicated to the "Experimental Mechanics of Materials and Structures". He was also a member of the AFM management board.

He was a member of the "Haut Comité Mécanique", where his opinions were much sought after, and he was also the associate editor of "Mechanics and Industry" the journal of the AFM.

It is not possible to give an exhaustive description of the mass of activities pursued by Alain Vautrin throughout his career.

He now lies at the foot of Mont Ventoux, where he had a family home.

We express our sincerest sympathy to his wife and two children.

Alain will remain among us thanks to everything he contributed to the mechanical engineering community.

M. Lebouché

President of the Haut Comité Mécanique
J.M. Théret

President of the $A F M$ 